\title{
A conversão do sertão capelas e a governamentalidade nas Minas Gerais*
}

\section{The conversion of the hinterland chapels and governamentalidade in the Minas Gerais}

\author{
Francisco eduardo de ANDRADE \\ Doutor em História pela USP \\ Pesquisador - UEMG/ Arquivo J udicial de Pitangui \\ Rua Alegrete, 480/ 306 - Sagrada Família - Belo Horizonte - MG - CEP 31 035-380 \\ franciscodea@hotmail.com
}

\begin{abstract}
RESUMO 0 artigo trata da instituição das capelas no território das Minas Gerais, considerando a sua significação política e a sua relação com o enquadramento social da população. Procura-se avaliar essa prática de poder, desde a fundação pelos patronos coloniais até o reconhecimento eclesiástico e régio. Observando-se os laços políticos na segunda metade do século XVIII, verifica-se ainda que as capelas, mecanismos de poder senhorial e de normalização dos súditos, tinham um papel fundamental na governamentalidade do Estado, especialmente nas fronteiras.
\end{abstract}

Palavras-chave capela, poder político, governo

ABSTRACT This paper is concerned with the establishment of chapels in Minas Gerais, taking into account its political meaning and its relationship with the social fitting of the population. Power practices are evaluated, since foundations of the chapels by colonial sponsors to their ecclesiastical and

\footnotetext{
Artigo recebido em 27/06/2006. Aprovado em 22/03/2007.

(A pesquisa que resultou neste artigo teve 0 apoio do CNPq. Agradeço a esta instituição a concessão de bolsa de recém-doutor, no departamento de História da UFMG, para a realização deste trabalho).
} 
royal admissions. Considering political bonds on the second half of the eighteen century, one verifies that chapels - a way of power of owners and subject regulation - had a fundamental role in the government, mainly at frontiers.

Key words Chapels, political power, government

\section{O lugar das capelas e os arraiais das Minas Gerais}

Em contextos agrícolas e vigorosamente rurais da capitania de Minas Gerais, chegou-se a concluir que o arraial surgira em conseqüência da fabricação da capela. Contudo, os laços estreitos entre a conformação do arraial e o campo que o sustinha, principalmente com a generalização de roças e a criação de gado, torna sem sentido indicar essa causa primária do núcleo de povoamento. Compondo a relação urbanização-instituição eclesiástica de modo historicamente dinâmico e diversificado, verifica-se que a existência de uma capela, mesmo que não correspondesse a uma povoação com edificações e rede de relações locais visíveis, não podia significar ausência de um lugar estratégico - cruzamento de rotas, confluências de rios, passagens obrigatórias, fertilidade e salubridade locais, condições de acesso -, onde pousos e ranchos, esporadicamente, permitiam trocas e algum nível de sociabilidade. Assim, o lugar da capela, manifestando 0 movimento dos entrantes e povoadores, com certa evidência, surgia antes da instituição da capela. ${ }^{1}$

A historiografia que relaciona sociabilidade religiosa e urbanização nas Minas observa uma correlação natural (ou praticamente espontânea), nas primeiras décadas do século XVIII, entre o povoamento minerador, o arraiale a sua capela, enquanto, na conjuntura econômica agropastoril das décadas finais, indica que as capelas rurais é que atraíam o povoamento. Haveria, neste último caso, a deliberação dos fazendeiros construtores da capela, seguindo, às vezes, uma espécie de plano de fundação do povoado.

1 Sobre o significado e o papel das capelas nas Minas Gerais, ver VASCONCELOS, Diogo de. História antiga de Minas Gerais. Belo Horizonte: Itatiaia, 1999, p.149, 188; VASCONCELOS, Salomão de. Bandeirismo. Belo Horizonte: Biblioteca de cultura, 1944, p.64; VASCONCELLOS, Sylvio de. Vila Rica. Formação e desenvolvimento - residências. São Paulo: Perspectiva, 1977, p.17, 44-45; VASCONCELLOS, Sylvio de. A arquitetura colonial mineira. Barroco, n.10, 1978/9; BARBOSA, Waldemar de Almeida. A decadência das Minas e a fuga da mineração. Belo Horizonte: Universidade Federal de Minas Gerais, 1971, p.152. Recentemente surgiram discussões abrangentes sobre a relação entre as capelas e a urbanização nas Minas: FONSECA, Cláudia Damasceno. Pouvoirs, villes et territoires. Génese et représentations des espaces urbains dans le Minas Gerais (Brésil) - début du XIXe siècle. Paris: EHESS, 2001. (Tese, doutorado em História); MATA, Sérgio Ricardo. Catolicismo popular, espaço e proto-urbanização em Minas Gerais, Brasil. Séculos XVIII-XIX. Colônia: Faculdade de Filosofia da Universidade de Colônia, 2002. (Tese, doutorado em História). O lugar compreende uma demarcação estratégica (simbólica e política) do espaço determinando aqui um posto "próprio" de querer, poder e saber. CERTEAU, Michel de. A invenção do cotidiano: artes de fazer. Tradução de Ephraim Ferreira Alves. Petrópolis: Vozes, 1994, p. 99-102. 
No entanto, o esquema não se mostra atento à problemática da diversificação econômica (agricultura, criação, mineração, manufatura, comércio fixo e ambulante) que sempre caracterizou o povoamento agrominerador em Minas Gerais. Nessas Minas, os movimentos da vida econômica dos habitantes não se apresentavam tão demarcáveis assim, e nem eram excludentes as alternativas de trabalhos e ofícios, tendo-se para isso possibilidade. A relação simples entre mineração e agricultura também tende a manter na obscuridade os diferentes modos de trabalho e vida, correspondentes às duas atividades, e os seus protagonistas - os posseiros, sesmeiros, agregados, moradores de favor, foreiros, jornaleiros, faiscadores, mineradores, garimpeiros. Apoiar-se simplesmente no regime legal de sesmarias ou no Regimento das minas de 1702, como se tem feito, pouco adianta na análise dessa problemática. 0 cotidiano da religiosidade pública das capelas era animado pela conjunção desses modos de vida.

$\mathrm{Na}$ verdade, as explicações da criação das capelas - e dos arraiais - hesitam entre uma situação econômica tendente aos ganhos, que conferiu uma ocupação espontânea (ou livre) do espaço, e os atos fundadores decorrentes de uma vontade religiosa e política dos agentes, calculando os interesses econômicos. Todavia, vale notar que as ações colonizadoras tanto se apresentavam condicionadas ou marcadas por disposições imperativas, quanto obedeciam às estratégias ou táticas, nas mais diversas situações. Havia, de fato, um agudo senso de oportunidade (ou de ocasião) regendo os agentes coloniais, tanto em relação aos meios de vida, quanto no que se referia aos poderes da organização administrativa (eclesiástica e civil) e jurídica.

As capelas, no espaço colonial, não deixavam de atenderàs motivações específicas da vida dos habitantes, como atesta a valorização notável dessas instituições religiosas, apesar das suas funções (é certo que marcadas por desvios) de enquadramento político da população e de enraizamento territorial do Poder do centro (a instância do Rei e dos seus representantes diretos).

Deve-se assinalar que a dimensão política da devoção católica e o papel político-administrativo da sociabilidade religiosa foram investigados nos estudos sobre as irmandades mineiras, e percebeu-se o religioso como peça-chave da engrenagem de centralização do Estado. Segundo Caio Boschi, "através delas e com elas [irmandades], [a Coroa] desenvolveu mecanismos de amortecimento das manifestações sociais que Ihe eram hostis. A religião nas Minas coloniais, encarnada nas irmandades, não foi fator de contestação do Antigo Regime". ${ }^{2}$ As irmandades, atendendo às diretrizes do Estado (a instância régia), serviam para apaziguar o conflito

BOSCHI, Caio César. As diretrizes metropolitanas, a realidade colonial e as irmandades mineiras. Revista Brasileira de Estudos Políticos, Belo Horizonte, n. 65, p.142, jul 1987. 
social e as tensões de uma situação política opressiva, quando prestavam assistência material e espiritual aos irmãos. ${ }^{3}$

A dificuldade aqui reside na unilateralidade da ação política dessas perspectivas de uma organização estatal moldada no/ pelo regime da Coroa. ${ }^{4} \mathrm{~A}$ centralização - como estratégia da Coroa - seria uma força a qual, partindo das autoridades régias, todos os coloniais aderiam, sob cooptação, ou então resistiam. Não transparecem assim os agentes coloniais que, explorando os mecanismos jurídicos e administrativos dos enlaces do Estado, construíram e reconstruíram a experiência política desta condição de Poder. A vivência religiosa nas Minas, e as suas formas de expressão, estiveram permeadas de atritos, rupturas e recomposições que deviam afetar qualquer plano estratégico (alguma vez concebido) de dominação política (ou centralizadora). Marcos Aguiar estudou a organização interna das irmandades de negros e mulatos de Vila Rica e pôde observar os conflitos de poder, ou de jurisdição, entre os irmãos e as autoridades eclesiásticas e civis. Tirando proveito das relações institucionais tensas, no século XVIII, entre a esfera eclesiástica (bispos, visitadores e párocos) e a esfera governamental, os irmãos conservavam-se no meio desse cruzamento de poderes, visando, tanto quanto possível, garantir a autonomia da vida confrarial. Ao mesmo tempo, esta servia de porta de entrada para outros anseios e formas de expressão cultural:

As irmandades [de negros e mulatos] apareciam como condução privilegiada, fornecendo práticas sociais, linguagem e formas de ação coletiva, para setores da sociedade, em busca de um lugar de reconhecimento dos seus interesses, valores, atitudes, visão de mundo, enfim. ${ }^{5}$

Já foi salientado que, no mundo português do Antigo Regime, a sociabilidade das capelas modelava a vida social das comunidades. Na demarcação do poder, o funcionamento litúrgico das capelas, mantidas por irmandades ou por agentes familiares, consagrava as posições políticas e sociais dos fiéis e promovia o sentimento de corpo. ${ }^{6}$ Assim, não somente exprimiam a hierarquia social do poder, mas contribuíam com eficácia para

3 Cf. BOSCHI, Caio César. As diretrizes metropolitanas, a realidade colonial e as irmandades mineiras, p.142-145.

4 HESPANHA, António Manuel. A constituição do Império português. Revisão de alguns enviesamentos correntes.. FRAGOSO, J.; BICALHO, M. F. B.; GOUVÊA, M. F. S. (Ed.). O Antigo Regime nos trópicos: a dinâmica imperial portuguesa (séculos XVI-XVIII). Rio de J aneiro: Civilização Brasileira, 2001, p.165-188; ANASTASIA, Carla Maria J unho. Vassalos rebeldes: violência coletiva nas Minas na primeira metade do século XVIII. Belo Horizonte: C/ Arte, 1998, p.137-140: "As reiteradas tentativas metropolitanas de acomodação com os atores coloniais sugerem, no que diz respeito à administração da Capitania de Minas Gerais, a impropriedade de se conceber 'um projeto apriorístico' de colonização, absolutamente mercantil e predatório. Sem dúvida, é mais adequada a idéia de um processo de colonização, no qual os atores interagiram conforme as contingências se lhes apresentaram".

5 AGUIAR, Marcos Magalhães. Vila Rica dos confrades. São Paulo: FFLCH/ USP, 1993, p.289. (Dissertação, mestrado em História).

6 CURTO, Diogo Ramada. A cultura política. In: MAGALHÃES, J oaquim Romero (org.). História de Portugal. No alvorecer da modernidade (1480-1620). Lisboa: Estampa, 1997, v.3, p.126-128; BETHENCOURT, Francisco. A igreja. In: MAGALHÃES, J oaquim Romero (org.). História de Portugal. No alvorecer da modernidade (1480-1620). Lisboa: Estampa, 1997. v.3, p.139-143. 
a sua construção ou representação. O ritual mais costumeiro da missa assumia um papel político de disciplinar as vontades dos assistentes, angariar respeito para os poderosos e conferir autoridade. Por isso, havia sempre ocasião para o reverso do enquadramento: o confronto, o agravo ou a reação violenta à sujeição. O espaço cênico e a teatralidade ritual dos gestos e da linguagem, durante o ofício divino, deviam agir no mesmo sentido persuasivo e, dependendo do entendimento rude (dos escravos, por exemplo, segundo alguns missionários), dobrar as resistências através das imagens expressivas de piedade religiosa. ${ }^{7}$ As Constituições Primeiras do Arcebispado da Bahia, em 1707, haviam preconizado as demonstrações exteriores da devoção católica que, difundindo os exemplos de virtudes e comportamentos, mantinham a conversão dos neófitos ou dos escravos africanos. ${ }^{8}$ Nuno Marques Pereira fez uma comparação esclarecedora no seu Compêndio Narrativo do Peregrino da América, publicado em 1728: assim como o (seu) livro edificante, que é templo verdadeiro de Deus, deve a igreja ser bem paramentada, "para lisonja do gosto, agrado da vista, recreio da vontade". ${ }^{9}$

\section{Das capelas dos senhores às capelas públicas}

As capelas funcionavam, então, como mecanismos de configuração (ou dispositivos) de poder. Nos sertões das Minas Gerais do século XVIII, os senhores (donos de escravos e terras), agentes de uma rede familiar e clientelista, costumavam fundar/ instituir capelas (com a aprovação episcopal), ou então dotá-las, determinando um patrimônio em terras e rendimentos para manutenção dos ofícios sagrados nos lugares onde houvesse a necessidade de assistência espiritual. Esta assistência aos fiéis, fazendo-se constante, nunca se reduzia ao núcleo doméstico do senhor que incluía, num sentido ampliado da época, o chefe, a esposa, os filhos, os agregados (com parentesco ou não) e os escravos. ${ }^{10}$

7 Cf. CURTO, Diogo Ramada. As práticas de escrita. In: BETHENCOURT, Francisco \& CHAUDHURI, Kirti (orgs.) História da Expansão Portuguesa. O Brasil na balança do Império (1697-1808). Lisboa: Círculo de Leitores, 1998, p.452-453

8 Cf. MOTT, Luiz. Cotidiano e vivência religiosa: entre a capela e calundu. In: SOUZA, Laura de Mello e (org.). História da vida privada no Brasil: cotidiano e vida privada na América portuguesa. São Paulo: Companhia das Letras, 1997, p.162.

9 PEREIRA, Nuno Marques. Compêndio Narrativo do Peregrino da América [1 $1^{\mathrm{a}}$ ed. 1728]. Rio de J aneiro: Publicações da Academia Brasileira, 1939, p. 7.

10 Não se deve confundir a família, e seu significado sociocultural, com o domicílio, que supõe a coabitação dos seus membros. Na América portuguesa, a família podia designar tanto aqueles que morassem juntos, com relações de parentesco ou não entre si (sentido mais estrito), quanto aqueles que, embora vivessem em outros lugares (até em Portugal), fossem considerados, por laços rememorados, membros familiares. Todos eles compunham a parentela, cujo sentido parece mais vago ainda. Contudo, é certo que o sentido de "família" e o papel desempenhado por cada um dos envolvidos, pelo menos para os seus agentes, variavam conforme as situações e as ações ou estratégias em jogo. Isso abria espaço para manipulações de significados tendentes a favorecer pleitos ou a atuação que, ao final, configuravam o grupo familiar. As estratégias dos seus agentes, assim, não deviam ser condicionadas somente pelo círculo familiar da casa, mas desdobravam-se segundo a rede de aliança e de parentesco envolvida. Cf. SILVA, Maria Beatriz Nizza da. História da família no Brasil colonial. Rio de J aneiro: Nova Fronteira, 1998 ; FIGUEIREDO, Lu- 
A administração dos rendimentos da capela era geralmente controlada pelo instituidor (e sua família) que, sendo reconhecido pelo bispo ou principalmente pela Coroa, obtinha o privilégio do padroado local, figurando como administrador/ patrono (ou padroeiro) da capela. ${ }^{11}$ Isso conferia prestíg io ao senhor, e garantia para o grupo familiar uma posição destacada na localidade que induzia ou reforçava as alianças.

Havia-se previsto em lei alguns privilégios para esses patronos, além do direito de gerir diretamente as rendas do patrimônio eclesiástico. Tinham o direito de apresentação de candidato ao benefício eclesiástico da capelania (conferido pela autoridade episcopal). Evidentemente era indicado para o posto de capelão um clérigo que tivesse ligações de parentesco ou de amizade com o instituidor. Não era preciso que os patronos leigos abrissem concurso (como acontecia em casos de padroados eclesiásticos) para preenchimento da vaga, bastando que escolhessem alguém "digno, mas não o mais digno".

Também tinham o direito de buscar auxílio, em situações de necessidade ou de pobreza (avaliada conforme a qualidade do patrono), nos rendimentos da capela. Certa doutrina jurídica chegava a considerar que o patrono pudesse ser favorecido costumeiramente com os frutos da sua instituição ou dotação. ${ }^{12} \mathrm{Na}$ capela de Nossa Senhora da Conceição de Cachoeira do Brumado, termo da cidade de Mariana, os moradores haviam acatado tal direito útil, que foi observado pelo visitador do bispado em 1768:

Sou informado que o dotador desta capella está vivendo no mesmo patrimônio do seo dote desde vários annos que se acha em execução [as obras do templo] attendendo a liberalidade com que fez o ditto dote e idade decrepita em que se acha com pobreza mando aos aplicados Procuradores desta capella e zeladores della que concluam a execuçam como for possível no estado em que se acha o dotador e lhe dou faculdade para poderem contornar no mesmo estado e attenderem com caridade a pobreza e idade decrépita em que se acha de que faram entre si clareza do bem que lhe fizerem na vida e na sua morte (...). ${ }^{13}$

ciano Raposo de Almeida. Barrocas famílias: vida familiar em Minas Gerais no século XVIII. São Paulo: Hucitec, 1997; BRÜGGER, Silvia Maria J ardim. Minas patriarcal - família e sociedade (São J oão del Rei - séculos XVIII e XIX). Niterói: ICHF/ UFF, 2002. (Tese, doutorado em História). Ainda, Cf. RAMOS, Donald. Marriage and the Family in Colonial Vila Rica. The Hipanic American Historical Review [HAHR], v.55, n.2, 1975.

11 TAVARES, J eronymo Vilella de Castro. Compêndio de Direito Público Eclesiástico para uso das faculdades de direito do Império [1 $1^{a}$ ed. 1853]. Rio de J aneiro: B. L. Garnier, 1882, p.158. O governo do bispado fiscalizava a obediência aos preceitos canônicos de fundação das igrejas. Em 1728, quando apareceram dois dotadores interessados na ereção de uma capela no lugar de Camapuã, freguesia de Nossa Senhora da Conceição dos Carijós, comarca do Rio das Mortes, um deles teve que abrir mão do direito de padroado para que a sua doação (quatrocentos mil réis do vínculo de uma roça) fosse admitida pelo bispo do Rio de J aneiro - AEAM [Arquivo Eclesiástico da Arquidiocese de Mariana], J uízo Eclesiástico, Capelas [Avulsos], caixa 3B.

12 HESPANHA, António Manuel. Os bens eclesiásticos na época moderna. Benefícios, padroados e comendas. In: TENGARRINHA, J osé. História de Portugal. São Paulo: Ed. UNESP, 2000, p.90-91.

13 Tombo/Cachoeira do Brumado. In: RODRIGUES, Flávio Cameiro (org.). Cademos Históricos do Arquivo Eclesiástico da Arquidiocese de Mariana. Mariana: Editora D. Viçoso, 2004. v.2, p.67, 2004. 
Mais do que simplesmente servir de reserva material, a capela produzia um capital simbólico muito importante na projeção política do patrono. Ele era honrado com o direito às preces, aos assentos especiais nos cultos e à precedência em cerimônias e procissões. 0 patrono distinguia-se ainda pelo direito a uma sepultura em lugar privilegiado da igreja. ${ }^{14}$ Durante os ofícios sagrados, o capelão certamente não deixava de fazer incensações que prestigiavam o patrono, ou algum aliado dele, e de pronunciar sermões nos quais só figuravam as virtudes dos poderosos. Assim, como o capelão dependente praticava não representar o que ocorria realmente, havia sempre o risco da mera ornamentação discursiva. Devia-se, ao menos, procurar algum proveito pastoral até nas adulações vazias. 0 visitador do bispado de Mariana, no século XVIII, lamentou que os pregadores somente compusessem "flores de conceytos aéreos e elevados". Advertindo-os, o visitador fez a seguinte recomendação: "em todos os seos Sermoens e ahinda panegíricos misturem discurços ascéticos e doutrinaes em que exagerem a virtude e afeem o vicio e o peccado". ${ }^{15}$

As capelas autorizadas e matrizes tinham imunidade quanto à justiça secular, mas os legisladores régios preveniram os efeitos abusivos do uso deste privilégio. Admitia-se que elas fossem couto para os fiéis livres que tivessem praticado crime merecedor de pena de morte ou de qualquer "pena de sangue". A Igreja tinha jurisdição nas causas dos criminosos asilados. No entanto, o direito à imunidade dos templos não se aplicava àqueles cujos crimes mostraram intenção premeditada ou a deliberação de ofender outrem (causar o "mal"). Tudo dependeria da motivação que deu origem ao malefício. ${ }^{16}$

Na segunda metade do século XVIII, e até o fim do período colonial, a Coroa procurou assumir o controle dos institutos eclesiásticos. A lei de 9 de setembro de 1769 obrigou a necessidade de licença régia para 0 estabelecimento de capelas de missas. Nos termos dessa lei, e nos do alvará que retomou os seus princípios em 20 de maio de 1796, as "capelas insignificantes", com rendimentos "que nem podem principiar família no terceiro estado, nem conservar o decoro das que já se acham elevadas aos graus de nobreza", podiam ser abolidas imediatamente. ${ }^{17} \mathrm{~A}$ forte restrição régia, com essas leis, à prática de vincular bens e dinheiro para capelas de missas dedicadas às almas, segundo as costumeiras disposições testamentárias, afetava nitidamente o tamanho dos patrimônios eclesiásticos e os rendimentos dos ofícios espirituais. ${ }^{18}$

14 HESPANHA, António Manuel. Os bens eclesiásticos na época moderna. Benefícios, padroados e comendas, p. 90

15 Visita à igreja de Nossa Senhora de Nazareth de Cachoeira do Campo. In: RODRIGUES, Flávio Carneiro (org.). Cademos Históricos do Arquivo Eclesiástico da Arquidiocese de Mariana, p.93.

16 Ordenações Filipinas, Livro 2, Título 5. Em http://www.uc.pt/ihti/proj/filipinas/ordenaçoes.htm. 11/08/01.

17 SILVA, Maria Beatriz Nizza da. Ser nobre na Colônia. São Paulo: Ed. UNESP, 2005, p.196-197.

18 Ordenações Filipinas, Aditamentos, p.1057- 1061. 
Essa interferência da Coroa na organização religiosa dos fiéis colocava em cena a exclusividade régia na concessão do direito do padroado sobre as capelas. As pretensões políticas regalistas dos governos pombalino e pós-pombalino, conferindo um lugar específico de poder religioso à instância diocesana, forjavam uma juris dição eclesiástica dependente ou mesmo incompetente para julgar pleitos de funcionamento ou de instituição de igrejas. ${ }^{19}$ Expressão da legitimidade do uso dos poderes na época, diversos instituidores requeriam e obtinham na corte o padroado das suas capelas, como Antônio Furtado Leite e seu irmão, J oão Furtado Leite, os fundadores da capela de Cocais, que conseguiram o direito por alvará régio em 12 de agosto de $1769 .{ }^{20}$

Formalmente, os bispos deviam prover os postos eclesiásticos em clérigos (ditos opositores) que, dirigindo-se à Coroa (detentora do padroado das igrejas coloniais), eram escolhidos para exercer o múnus espiritual. Entretanto, foram os bispos que, tradicionalmente atentos às circunstâncias coloniais, instituíram os benefícios eclesiásticos nas Minas sem recurso à Coroa, criando paróquias - curatos - e admitindo capelas filiais. ${ }^{21}$ Os governantes episcopais sempre cuidaram da criação das paróquias (obrigados a desmembramentos ou anexações dos seus territórios) e as proviam em vigários encomendados. Como já foi indicado acima, esses curatos foram predominantes nas Minas durante o século XVIII. O problema jurisdicional entre os poderes civis e religiosos transparece nesse contexto, quando se observa que numa instituição paroquial deviam concorrer o padroado régio, responsável pela dotação de igrejas e pela manutenção do pároco, e a autoridade episcopal que havia promovido o benefício e o concedia ao opositor designado pelo patrono. ${ }^{22}$

As capelas fundadas pelos habitantes subordinavam-se, pelo menos teoricamente, às matrizes, tornando-se capelas filiais. Estas podiam assumir uma dimensão pública, quando havia ampliação do número de assistentes e as atividades religiosas (cultos e obrigações sacramentais) ficavam constantes. A grande proliferação de capelas filiais, sempre mais numerosas que as matrizes, resultava também de adaptação às condições sociais e econômicas das Minas. Os párocos, numa petição ao Rei, encaminhada por este ao bispo de Mariana, tentaram resguardar o direito às taxas da desobriga pascal, geralmente criticado pelos coloniais, explicando como

19 De qualquer modo, é muito complexa a definição das relações entre os campos político e religioso em Portugal e nas suas possessões ultramarinas da segunda metade do século XVIII. GOUVEIA, António Camões. 0 enquadramento pós-tridentino e as vivências do religioso. In: HESPANHA, António Manuel (org.). História de Portugal. O Antigo Regime (1620-1807). Lisboa: Estampa, v.4, p.263-265, 1998.

20 TRINDADE, Raimundo. Instituições de Igrejas no Bispado de Mariana. Rio de J aneiro: SPHAN, 1945, p.93.

21 TRINDADE, Raimundo. Instituições de Igrejas no Bispado de Mariana, p.13-14.

22 "Instituição é o outorgamento de um benefício à apresentação do que tem direito de padroado. Para conseguir-se um benefício por este meio são necessárias a instituição e a apresentação: esta compete ao padroeiro, aquela ao bispo, que é quem confere o benefício à pessoa oferecida, salvo havendo obstáculo." TAVARES, J eronymo Vilella de Castro. Compêndio de Direito Público Eclesiástico para uso das faculdades de direito do Império, p.158. 
as capelas de assistência pública viraram igrejas coladas desde o povoamento fronteiriço:

aquelas paróquias tinham principiado por capelas de campo, e que se indo nos seus distritos povoando alguns lugares, se erigira em cada um deles sua capela por mais comodamente se administrarem os sacramentos nela àqueles moradores que movidos de devoção, ou comodidade que nisto tinham, à sua custa constituíam côngrua ao capelão da tal capela tirando sempre paroquiano da matriz, cujo cura por si, ou pelos ditos capelães das capelas, os desobrigava da quares ma e administrava os mais sacramentos, ficando assim legitimamente paroquiados com aprovação vossa [do bispo], conservando-se em paz portantos anos, até que eu fui servido criar de natureza colativa as ditas paróquias, a provê-las de párocos porconcurso de exames que mandei fazer, no qual tinham eles suplicantes sido opositores às mesmas igrejas, assim e da maneira que elas eram, o que lhes dava tal direito (....).

Os párocos das Minas Gerais ainda avisavam o Rei sobre a "inconstância dos povos" afetando os seus direitos, porque havia capelas filiais com maior número de fregueses e mais rendimentos do que as suas matrizes, devido à entrada de habitantes atraídos aos descobertos de ouro. ${ }^{23}$ Por seu turno, as capelas filiais importantes ou mesmo curatos podiam retroceder e voltar à posição antiga de capelas senhoriais. A capela de Santo Antônio do Morro, que havia sido instituída pelo tenente coronel Maximiano de Oliveira Leite em sua fazenda, segundo o relato do cura feito em 1833, é "hoje de sua viúva e herdeiros, a qual sendo curada em princípios, veio pela decadência de seus habitantes e mesmo por ser lugar menos cômodo, a ficar particular daquela fazenda e se mantém por expensas daquela família" ${ }^{24} 0$ que aconteceu ali foi estritamente a decadência do lugar, com a decorrente diminuição da população, ou houve também mudança no prestígio político da família poderosa?

A recomendação oficial era a de que o vigário garantisse a subsistência dos capelães, na medida em que estes oficiavam em nome daquele superior que tinha a posse do benefício paroquial (direitos e taxas). Contudo, na prática, além de custear as fábricas das capelas, a manutenção efetiva dos capelães recaía, direta ou indiretamente, sobre os habitantes dos lugares (sítios ou arraiais) unidos por laços corporativos (associações de devoção ou famílias poderosas), e isso aumentou a tensão e os conflitos relacionados à assistência religiosa. Ainda assim, os capelães aproveitavam as oportunidades econômicas e políticas e faziam seus negócios lucrativos, e bem mundanos, inserindo-se em diversas atividades produtivas, desde a mineração até o artesanato.

23 AEAM, Prateleira W/ Livro 24. Cartas, provisões, ordens e alvarás régios que respeitam ao Bispado de Mariana - 1752 1822, f. 32-33. Ordem régia pelo Tribunal da Mesa da Consciência e Ordens, 28 de setembro de 1758.

24 TRINDADE, Raimundo. Instituições de Igrejas no Bispado de Mariana, p. 215. 
Os capelães curas e o pároco repartiam os rendimentos obtidos com a cobrança de emolumentos advindos dos batizados, casamentos e enterros realizados nas capelas filiais. ${ }^{25}$ No entanto, os tratos entre 0 vigário e os capelães podiam variar; na Vila do Príncipe, segundo o viajante francês Saint-Hilaire, no início do século XIX, o padre de uma igreja sucursal recebia um "salário fixo" do vigário da vila, o qual tinha um procurador para cobrar as conhecenças dos fiéis aplicados. Nos arraiais prósperos, as confrarias resistiam a uma tácita subordinação às matrizes e contratavam os próprios capelães, que assim se viam instigados a assumir atribuições, tais como ofícios de festividades e de funerais, pertencentes aos párocos. ${ }^{26}$ Esses ajustamentos, permeados de situações conflituosas, eram peças fundamentais no jogo de poder eclesiástico em cada vigairaria, e eles dependiam da generosidade obrigada dos fiéis.

\section{Práticas de governo e capelanias na fronteira}

O Conde de Valadares, governador da capitania de Minas Gerais, escreveu, em 25 de setembro de 1769, para Inácio Correia Pamplona, mestre de campo regente, sobre o modo político de agir na conquista da picada de Goiás: "o principiar pela casa de Deus fez muito bem. Sem este princípio não se conseguirão esses acertados desígnios de vossa mercê". ${ }^{27}$

Pamplona saíra de sua fazenda dias antes, chefiando uma expedição portentosa em direção ao sertão do oeste. O relato diário dessa jornada, seguindo instruções de Valadares, é, ele mesmo, uma prática de governo: descreve, investiga e representa o espaço; desvela e apreende os habitantes. ${ }^{28}$ Mas o relato recolhe ainda o jogo de poder da conquista e a condição de governabilidade (ou a governamentalidade) dos coloniais. ${ }^{29}$ Além do

25 "Os emolumentos destes [capelães] são objeto de uma convenção particular entre eles e os curas [párocos]; mas quando o rendimento de uma sucursal é um pouco maior, sucede, às vezes, que o pároco, em lugar de pagar o capelão, recebe dele um pagamento, e então a sucursal torna-se para o pároco um espécie de fazenda arrendada". SAINT-HILAIRE, Auguste de. Viagem pelas províncias do Rio de J aneiro e Minas Gerais. Tradução de Vivaldi Moreira. Belo Horizonte/ São Paulo: Ed. Itatiaia/ Ed. USP, 1975, p.83.

26 SAINT-HILAIRE, Auguste de. Viagem pelas províncias do Rio de J aneiro e Minas Gerais, p.28, 81; Mapa estatístico oferecido à Mesa da Consciência e Ordens no ano de 1826 pelo de 1825. TRINDADE, Dom FreiJ osé da Santíssima. Visitas pastorais de Dom FreiJ osé da Santíssima Trindade (1821-1825). Belo Horizonte: Centro de Estudos Históricos e Culturais/ Fundação J oão Pinheiro, IEPHA, 1998, p.308-314; AGUIAR, Marcos Magalhães. Vila Rica dos confrades, p.266-289.

27 APM. Arquivo Público Mineiro, Seção colonial, cód. 165, folha 90v-91.

28 NOTÍCIA diária e individual das marchas[,] e acontecimentos ma(i)s condigno(s) da jomada que fez o Senhor Mestre de Campo, Regente[,] e Guarda(-)mor Inácio Corre(i)a Pamplona, desde que saiu de sua casa[,] e fazenda do Capote às conquistas do Sertão, até se tornar a recolher à mesma sua dita fazenda do Capote, etc.etc.etc. - Anais da Biblioteca Nacional, v. 108, 1988, p.47-113. A historiadora Laura de Mello e Souza foi, creio, quem primeiro se deteve no estudo desse texto. SOUZA, Laura de Mello e. Violência e práticas culturais no cotidiano de uma expedição contra quilombolas - Minas Gerais, 1769. REIS, J oão J osé, GOMES, Flávio dos Santos. Liberdade por um fio: história dos quilombos no Brasil. São Paulo: Companhia das Letras, 1996, p.193-212. Sobre Inácio Correia Pamplona e as suas entradas no sertão do oeste, entre as décadas de 1760 e 1780, ver BARBOSA, Waldemar de Almeida. A decadência das Minas e a fuga da mineração, p.117-137.

29 Considero aqui a instigante análise sobre a govenamentalidade da ordem social e política no século XVIII, quando o exercício do poder se converte em prática de governo, empreendida por FOUCAULT, Michel. A governamentalidade. Microfísica do poder. Tradução de Roberto Machado. Rio de J aneiro: Graal, 1979, p.277-293. A governamentalidade 
plano militar, as peças desse jogo, que deliberadamente condicionaram toda a ação ou gesto cotidiano da entrada, foram os rituais religiosos, as atitudes pastorais e a formação de capelas.

Inácio Pamplona apresentou-se um pacificador do sertão, administrando a justiça aos litigantes, até contra o próprio interesse, e promovendo o bem comum de todos. Representante do governador, ele era instrumento da paz, e por isso sua presença era necessária; revelava-se aqui a responsabilidade tradicional do poder régio na pacificação social. Um exemplo desse papel, entre outros referidos pelo escrivão do relato: "aqui acodiram várias pessoas, por causa de suas dúvidas, a quem o Senhor Mestre de Campo debateu com algumas persuações de que se seguiu o ficarem muntos em paz". ${ }^{30}$

Contudo, Pamplona não agiu só como uma autoridade estatal que aplicava as leis e seguia o regulamento para compor as partes em conflito e defender os direitos. Ele atuou na reforma dos modos de vida dos moradores ou dos entrantes e visou estimular a produção econômica.

Os principais aliados do regente nessa atuação de governo foram os padres, desde o capelão da expedição até os vigários das paróquias percorridas. Nos seus poemas laudatórios dedicados a Pamplona, os padres exortaram o representante do governador a favorecer, através da pastoral (esclarecida), a transformação da população embravecida. O vigário de Santa Ana do Bambuí compôs as seguintes quadras no momento do jantar:

(...)

Assim hoje a casa levantada

da senhora Santa Ana exclarecida

à gentílica prole embrabecida

será causa de ver(-)se destroçada

(...)

Se a Igreja por vós não fosse erguida

nunca o povo(,) Senhor(,) vos murmurava

nem a inveja fora em ódio convertida. ${ }^{31}$

As missas celebradas diariamente no alvorecer, no período da jornada (entre 18 de agosto e 27 de novembro), eram obrigação do capelão. Elas precediam os fatos notáveis e predispunham os acordos políticos e judiciais e as atividades de trabalho desenvolvidas em cada pouso (abertura

do Estado é um processo "constituído pelas instituições, procedimentos, análises e reflexões, cálculos e táticas que permitem exercer esta forma bastante específica e complexa de poder, que tem por alvo a população, por forma principal de saber a economia política e por instrumentos técnicos essenciais os dispositivos de segurança.". FOUCAULT, Michel. A governamentalidade, p.291-292. Cf. ORTEGA, Francisco. Habermas versus Foucault: apontamentos para um debate impossível. Síntese, Belo Horizonte, v.26, n.85, p.242-244, 1999.

30 NOTÍCIA diária e individual das marchas[,] e acontecimentos ma(i)s condigno(s) da jornada que fez o Senhor Mestre de Campo, Regente[,] e Guarda(-)mor Inácio Corre(i)a Pamplona, p.57.

31 NOTÍCIA diária e individual das marchas[,] e acontecimentos ma(i)s condigno(s) da jornada que fez o Senhor Mestre de Campo, Regente[,] e Guarda(-)mor Inácio Corre(i)a Pamplona, p.82. 
de caminhos, construção de capelas e ponte, estabelecimento de roças e exploração de ribeiros auríferos).

No dia 10 ua hora antes da manhã praticaram os Músicos e tambores[,] seu ordinário[,] e diário costume, ouvimos missa como sempre o fizemos, sem falha de um só dia, mandou o Senhor Mestre de Campo[,] ajuntar toda a gente que havia de toda a qualidade marchando na vanguarda deles ao som dos Instromentos, para o lugar da capela(;) ali com encansável deligência[,] e zeloso cuidado entrou a destribuir a gente para a laboração [de construção da capela-mor] que a cada qual competia. ${ }^{32}$

Quando a ocasião exigia, o capelão ministrava os sacramentos à gente desamparada: batizou crianças "que estava $(\mathrm{m})$ para lhe nacer os dentes", confessou e comungou alguns sertanejos. ${ }^{33}$

Houve rituais bastante solenes, como uma missa cantada (em cantochão), que foi celebrada pelo pároco de Santa Ana de Bambuí. A pregação especial foi encomendada ao coadjutor do pároco de Tamanduá. Essa missa solene buscou antever o bom resultado de duas bandeiras de exploração do sertão, e que se separaram do corpo principal da expedição. ${ }^{34}$

Ao fim da construção de uma ponte sobre o rio São Francisco, Pamplona ordenou uma procissão de ação de graças, na qual as imagens de Cristo crucificado e Nossa Senhora da Conceição foram reverenciadas. Os assistentes cruzaram a ponte cantando um Te Deum, em direção a uma capela que se construiu próximo, no caminho. Saindo da capela, depois de concluída uma ladainha com música, os devotos seguiram cantado orações para Nossa Senhora. No outro dia, depois de aterrarem a ponte, mas agora em "forma militar", foi cruzada a ponte novamente até a capela, indo o mestre de campo e o capelão na frente dos expedicionários alinhados em dupla, ao som de marcha com tambores, trompas e flautas. Depois da missa na capela, o cortejo voltou com a mesma formação até o alojamento. Ao fim, como completando a cerimônia de fundação, foi construída uma cruz defronte a ponte, "para ser reverenciada naquele lugar de todos os passageiros, como sinal da nossa redenção". ${ }^{35}$

Em um ato público determinado por Pamplona, visando a demarcação territorial e a fundação de um arraial, houve a inscrição de quatro cruzes num pau de sucupira, em cujo pé foi armado um altar e nele colocadas as imagens de Cristo e de Nossa Senhora da Conceição que conservaram durante a expedição. De joelhos, os assistentes rezaram, pedindo o bom

\footnotetext{
32 NOTÍCIA diária e individual das marchas, p.65.

33 NOTÍCIA diária e individual das marchas, p.58,83.

34 NOTÍCIA diária e individual das marchas, p.59.

35 NOTÍCIA diária e individual das marchas, p.61-62.
} 
sucesso da colonização que se seguiria, com o requerimento e a obtenção de terras de sesmarias. ${ }^{36}$

Tratava-se sempre de representar aquela redenção política e religiosa (ou seja, civilizadora) dos entrantes através da ação qualificada e precavida do governante. Contudo, os interesses senhoriais, ou particulares, eram constantemente admitidos. Na vizinhança da ponte do rio São Francisco e do novo caminho que seguia para ela, o mestre de campo havia "comprado", ou se apossado, de uma fazenda (as Perdizes). Por isso, muitas vezes, Inácio Pamplona foi duramente criticado e considerado, acima de tudo, um poderoso que visava tirar o maior proveito econômico possível (com a criação de gado ou o comércio) da situação de fronteira. ${ }^{37}$

0 exercício doméstico dos preceitos cristãos manifestava-se quando se rezava o terço, ao anoitecer, diariamente, na barraca de Pamplona. ${ }^{38}$ Essas demonstrações pessoais de afinidade religiosa ocorreram também quando o mestre de campo fez promessas aos santos de devoção, num caso grave de acidente e perigo de morte. ${ }^{39}$

Toda essa manifestação devocional cotidiana, aspecto já enfatizado por Laura de Mello e Souza na sua análise da expedição de 1769, permeia o desenrolar da jornada. ${ }^{40}$ Exagerando um pouco, pode-se dizer que 0 relato se espelhou na forma narrativa de uma visitação pastoral, desde a saída do séqüito com aparatosa matalotagem até o seu retorno ao ponto de origem, na fazenda onde morava o mestre de campo, perto da vila de São J oão del Rei.

Pamplona, auxiliado pelo seu capelão, mostrou preocupação com o exercício pastoral e a decência do ofício religioso, ordenando as melhorias (e reforma) dos templos e fundando capelas junto dos caminhos. Em Piuí, revoltou-se contra "a gente tão bárbara e e(n)dômita" que fez a capela virar um curral de gado. O comandante local, que provavelmente ocupava a função de padroeiro, havia vendido os ornamentos da igreja. 0 mestre de campo ordenou então que os moradores reconstruíssem a capela num prazo de três meses. Qualquer "rebelde" que fugisse a essa obrigação seria castigado. No arraial e sede da paróquia de Santa Ana do Bambuí,

36 NOTÍCIA diária e individual das marchas, p.77-78.

37 NOTÍCIA diária e individual das marchas, p.82,85,99.

38 NOTÍCIA diária e individual das marchas, p.65. 0 governador da capitania de Minas Gerais, Antônio de Noronha, em 1777, impôs limite às posições de autoridade do regente mestre de campo do sertão da picada de Goiás, justificando-se: "dei por cassadas e abolidas como repugnantes ao que S. M. tem determinado como ob-reptícias e sub-reptícias, por se fundarem em narrativas falsas e serviços imaginários que o sobredito mestre de campo nunca fez nas terras onde pretende arrojar jurisdição política e militar, que lhe não compete. Quanto mais que ainda que fossem verdadeiros esses serviços, não lhe podendo ser remunerados com aquelas prerrogativas que, na forma dos regimentos e ordens régias, pertencem aos capitães- mores." BARBOSA, Waldemar de Almeida. A decadência das Minas e a fuga da mineração, p.126.

39 NOTÍCIA diária e individual das marchas, p.60-61.

40 SOUZA, Laura de Mello e. Violência e práticas culturais no cotidiano de uma expedição contra quilombolas - Minas Gerais, 1769, p.199-201. 
Pamplona, aliado do vigário, envolveu-se com a construção da nova igreja, e impôs aos moradores a continuação da obra sob as ordens do vigário. ${ }^{41}$

Foram ainda constituídas novas capelas no caminho do sertão. A capela de São Francisco de Sales e Santa Maria foi construída pelos escravos de Pamplona, junto à ponte do rio São Francisco. Uma outra, dedicada à Nossa Senhora da Conceição, cujo patrimônio foi instituído pelo mestre de campo ao fazer a doação (por escritura) de uma fazenda, devia situar-se numa paragem apropriada ao arraial, nas vizinhanças do famoso quilombo do Ambrósio. ${ }^{42}$

Contudo, o que deve ser salientado nessa narrativa é a diferença no modo de apropriação colonial do espaço, na picada de Goiás e nascentes do rio São Francisco. 0 arraial e a capela expressavam a entrada (expedição de bandeira e enquadramento social) e a posse (de sesmarias ou de roças em caminhos autorizados) dos poderes das Minas Gerais. Essa composição apropriada do cenário público fazia parte do universo lusobrasileiro. Enquanto isso, o quilombo (arraial negro) revela-se também um ponto de referência no espaço territorial, ajustando-se às rotas, com suas roças, ranchos, teares, curtumes, forjas e paióis com mantimentos, mas que se desviavam dessa reforma pública e às pretensões da governabilidade política e econômica do Estado monárquico. ${ }^{43}$ Assim, no século XVIII, converter os coloniais às estratégias (ou desígnios) do Poder central (dos agentes régios), e conformá-los aos seus meios, era o problema do governo, cuja significação pareceu ainda maior quando se defrontou os negros e a gente mestiça do sertão. No fim da sua jornada de pacificação, o mestre de campo, na realidade nem tanto preocupado com a fundação do poder governamental (ou público), via-se obrigado, contudo, a seguir a lógica da segurança e do bem estar da população para justificar a violência e os próprios excessos cometidos.

\section{Conclusão}

Em dois mapas de partes da comarca do Rio das Mortes, na altura do grande campo de serras e das nascentes do rio São Francisco, marcou-se

41 SOUZA,Laura de Mello e. Violência e práticas culturais no cotidiano de uma expedição contra quilombolas - Minas Gerais, 1769, p.58, 64-67.

42 SOUZA, Laura de Mello e. Violência e práticas culturais no cotidiano de uma expedição contra quilombolas - Minas Gerais, 1769, p.60-61, 70, 100. 0 mestre de campo ainda fez outras demarcações de terras, atendendo à piedade religiosa (e aos anseios de distinção social): uma para a Santa Casa da Misericórdia de Vila Rica, e uma outra para o Senhor Bom J esus do Matozinho, de Lagoa Dourada. SOUZA, Laura de Mello e. Violência e práticas culturais no cotidiano de uma expedição contra quilombolas - Minas Gerais, 1769, p. 67, 101.

43 Por exemplo, em 1767, os atacantes de um quilombo localizado na freguesia de Pitangui encontraram e destruíram ali "quatorze ranchos de capim e plantas de roça" de milho, feijão, algodão, "melancias e mais fruta". GUIMARÃES, Carlos Magno. Mineração, quilombos e Palmares. Minas Gerais no século XVIII. In: REIS, J oão J osé, GOMES, Flávio dos Santos (orgs.) Liberdade por um fio: história dos quilombos no Brasil. São Paulo: Companhia das Letras, 1996, p.147-148. 
todo espaço com quilombos e arraiais ou capelas. Eles foram representados de maneira significativamente diferente. No mapa de meados da década de 1760, o símbolo da comunidade dos fiéis - um pequeno templo sem torre da capela -, circulado por uma linha, serviu para identificar os arraiais dos coloniais brancos. Anos depois, no mapa produzido para reter a conquista do mestre de campo Inácio Correia Pamplona, foram destacadas as capelas no sertão (sem que saibamos se elas corresponderam aos arraiais), e as distinguiram por meio de pequenos círculos coloridos, adornados com uma cruz. Quanto aos quilombos, embora fossem também identificados através de círculos no âmbito das serras e rios dos mapas, sua representação circular não implicou nenhum tipo de ornamento ou símbolo. ${ }^{44}$ Portanto, a capela constituía o povoamento dos coloniais cristãos. Fazia a diferença entre ser um arraial ou ser um quilombo.

Como já havia sugerido antes, essa composição da capela distinguia a legitimidade política e a legalidade da ocupação e apropriação territoriais. Sua relação com os núcleos de povoamento era complexa, e não deve ser analisada por uma simples relação causal. É certo que entre a entrada de ocupação e o povoamento, com algum grau de estabilidade, há diferenças de tonalidades muito difíceis de serem apreendidas. Daí, a dificuldade de estabelecer em que ponto do processo de colonização dessas Minas podemos situar a definição, edificação e/ ou instituição das primeiras capelas.

Quando se trata de um sítio ou lugar aonde se fez uma capela, é possível afirmar simplesmente, à maneira de alguns historiadores, que esta instituição religiosa produziu ou determinou o núcleo que se formou? Além da necessidade de investigar a diversidade das situações locais (sociais, econômicas, políticas e geográficas) que compuseram a relação capela-arraial, deve-se perguntar se não haveria sempre algo anterior à própria capela.

De fato, a capela não pode ser vista como uma instituição que surgia no espaço vazio do sertão (que, aliás, nunca foi vazio, sendo sempre trilhado por índios, negros ou pela arraia-miúda livre). Ela já devia resultar de um investimento simbólico, religioso, político e econômico no espaço percorrido pelos coloniais. Com a consolidação das atividades agropecuárias em Minas Gerais, na segunda metade do século XVIII, esse algo podia ser as oportunidades econômicas e políticas revigoradas nos lugares de fronteira ou nos pontos estratégicos e de passagem das rotas mercantis.

Por outro lado, merece correção supor que os mineradores fossem mais espontâneos, e que as suas capelas e as funções paroquiais surgissem

44 Mapa de todo o campo Grande tanto da parte da Conquista, q' parte com a Campanha do Rio Verde, e S. Paulo, como de Piuhy Cabeceyras do Rio de S. Francisco, e Goyases na entrada que se fez para os certoes das conquistas do Campo grande por ordem do Ilmo. Sr. Conde de Bobadela como se ordenou ao Capp.am Antônio Francisco França; Mapa da Conquista do Mestre de Campo Regente Chefe da Legião Ignacio Correya Pamplona. Por Manuel Ribeiro Guimarães. Cf. COSTA, Antônio Gilberto (org.). Cartografia da conquista do território das Minas. Belo Horizonte/Lisboa: Editora UFMG/ Kapa Editorial, 2004, p.180-181, 184. 
naturalmente conforme despontavam as devoções espirituais. Distante de uma institucionalização automática do religioso, deve-se admitir que nos arraiais ditos mineradores somente haveria a instituição das capelas e um ritmo de vida paroquial quando se definisse a jurisdição diocesana (e política) sobre as Minas - se do Rio de J aneiro ou da Bahia -, e fossem atendidos os direitos paroquiais dos capelães ou clérigos e resguardados os interesses senhoriais.

Fazer do enquadramento social e político das populações uma condição de governabilidade foi o problema marcante do Poder da Coroa, na segunda metade do século XVIII. Por isso, não se podia prescindir das capelas, nas quais o ofício pastoral conduzia à administração da vontade, sem oprimir-se a própria liberdade, do fiel católico e súdito. A pessoa do fiel, fruto do exame e dos procedimentos religiosos, conjugava-se, na prática pastoral, às virtudes ou necessidades do súdito (ou do cidadão) que se exercitava nos procedimentos do governo político. Por isso, os laços de poder, que se revelavam tensos e conflituosos, vinham subentendidos no compromisso religioso.

Advém dessa correlação entre os papéis religioso e político o fato de que, na capela (cenário dos ritos sacramentais que mediam a vida e instância pública de sociabilidade), o colonial poderoso - como patrono ou administrador da capela, parente ou aliado do sacerdote - ou, ainda, o governante encontrasse possibilidades de prestígio e mesmo de proveito material.

Contudo, seria demais afirmar que a tônica das relações entre o capelão e a família poderosa (ou a irmandade) fosse a mera dependência daquele a esta. Não que se deixasse de configurar entre os agentes uma relação clientelista.

Na realidade, o capelão (e principalmente o pároco) era peça importante no jogo de poder local ou familiar e sabia usar o capital religioso e simbólico que detinha. Se parente do patrono ou do dotador da igreja, ele próprio contribuía para a trama das estratégias ou táticas familiares. Além disso, 0 capelão costumava forjar certa autonomia, equilibrando-se entre os poderes eclesiásticos (pároco, autoridades diocesanas) e leigos da sua capela.

Por tudo isso, as capelas marcavam o espaço e ajudavam a compor as linhas de força entre os pobres, poderosos e autoridades régias, especialmente nas fronteiras dos territórios coloniais. Articulando-se aos núcleos de povoamento, as igrejas distinguiam-se da paisagem rústica do entorno e qualificavam os moradores. Pode-se deduzir, considerando-se os mapas militares, que mesmo os negros e os mestiços pobres desse mundo violento e permeável às usurpações, se vivessem sob a cruz das capelas - entre a sujeição e a proteção -, ancoravam melhor o uso dos seus direitos de posse e trabalho no sertão. 